\title{
はりの非線形振動に関する実験的補足 \\ EXPERIMENTAL SUPPLEMENTS FOR NONLINEAR VIBRATIONS OF BEAMS
}

高橋和 雄*

By Kazuo TAKAHASHI

\section{1. 緒言}

著者は文献 1)においてはりおよび薄板なごの連続体 の非線形振動を対象として Galerkin 法を用いて多自由 度系に置換する解法の収束性と安定性を吟味した。引き 続き, 本論文は同じ解法によるはりの非線形振動の解析 值の精度を検討するために非線形振動実験を実施し, 実 験值との比較を行うものである. 従来のはりの非線形振 動に関する研究は振動系を特定の基準座標を用いた 1 自 由度系と仮定する解法がほとんどである。このために, 非線形自由振動の振動数と振幅との関係, 振幅に伴ら振 動形の変動および周期的変動荷重が作用する場合の非線 形応答特性に関して, 多自由度系としての解析值と実験 值との定量的比較はいまだなされていない。そこで，本 論文は振幅によって振動形が変化する両端固定はりを対 象に非線形振動の解析值と奏験值との比較を行った結果 を報告するものである。

\section{2. 非線形振動実験}

\section{（1）実験装 置}

図一1 に示すように材質ジュラルミン製はり（有效長 さ $30 \mathrm{~cm}$, 幅 $30 \mathrm{~mm}$, 厚さ $1 \mathrm{~mm}$, 単位体積質量 $r=$ $2.85 \times 10^{-3} \mathrm{~kg} / \mathrm{cm}^{3}$, ヤング率 $E=0.71 \times 10^{6} \mathrm{~kg} / \mathrm{cm}^{2}(6.96$ $\left.\times 10^{6} \mathrm{~N} / \mathrm{cm}^{2}\right)$ ) を両端で曲げおよび軸方向変位に対して 固定条件を満足するように M-12のボルト 6 本学用いて 鉄製の治具に固定し，支持枠全体を図一2 に示すように 振動台上に振動方向と直角に設置した．振動実験は図一 2 のブロックダイアグラムを用いて実施された。試験片 は定尺 $(900 \times 1800 \mathrm{~mm})$ のジュラルミン板加ら 50 本程 度切り出し,このうちなるべく初期たわみの少ないもの

\footnotetext{
* 正会員 工修 長㥓大学助教授 工学部土木工学科
}
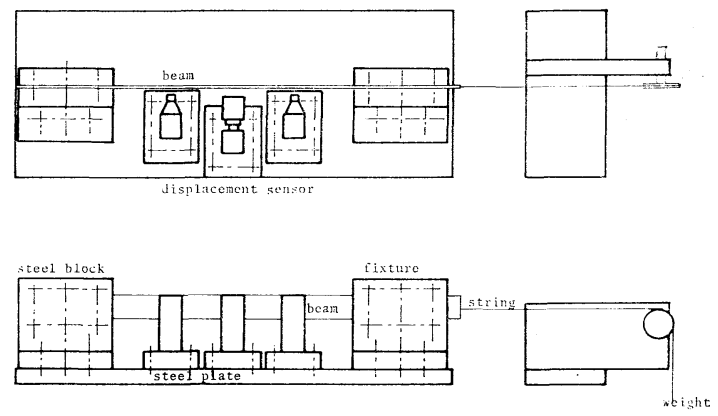

図-1 実験模型および支持枠

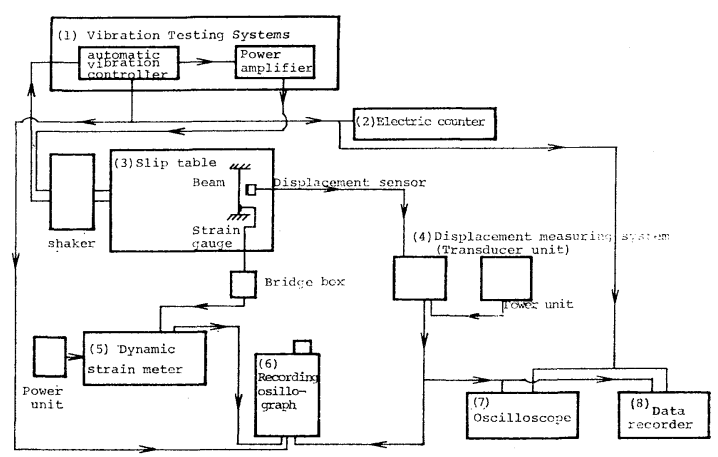

図一2 非線形振動実験のブロックダィアフラム

を選んで本実験に使用した．はりの材質であるジュラル ミンの線膨張係数は, 鉄の 2 倍以上の $23 \times 10^{-6} /{ }^{\circ} \mathrm{C}$ であ る.したがって,ジュラルミンは熱に対して不利である ために熱対策に十分な配慮が必要であることが判明し た. このために, 加振機の空冷ブロワー部から出る熱気 を実験室外に排除するとともに, 気温の変動が少ない冬 場の深夜の時間帯を選んで実験を行った。また，はりに 初期軸力が作用できるように設計されている. 軸力は, はりに鉄製のブロックを吊るして与えられた.

\section{（2）実験方法}

図一2 のブロックダイアグラムに従ってはりの非線形 
定常強制振動および自由振動実験を行っ た.まず，定常強制振動実験については加 振力を一定にするために一定の加速度で振 動台をコントロールしながら往復の自動掃 引実験を行った．はりの中央点㐨よび 4 分 の 1 点に設置された変位計センサーによ

り, はりの振動の相対変位を検出し, データレコーダー に入力の加速度波形とともに記録した. 中央点のセンサ 一ではりの振幅と振動数との関係を求め, 4 分の 1 点の センサーで逆対称振動をモニターするとともに，中央点 の変位の比によって振幅に伴う振動形の変動を求めた.

以上によって得られたはりの中央点の動的変位 $y$ をは りの回転半径 $r=D / \sqrt{12}$ ( $D:$ : りの厚さ) で無次元化 $(A=y / r)$ 乙, また, 加振振動数 $f$ を微小振動実験加ら 測定した 1 次対称振動の固有振動数 $f_{1}$ で無次元化 ( $\bar{\omega}$ $=f\left(f_{1}\right)$ して, 振幅比 $A$ と振動数比 $\bar{\omega}$ との関係を求め た.

次に, 非線形自由振動を求めるために定常加振状態の 振動台を急停止させた後の非線形自由振動をデータレコ ーダーに記録した. 次にこのデータをデータレコーダー のスピードを落としてオッシログラフペーパー上に出力 した. はりの中央点抢よび 4 分の 1 点の自由振動の時間 的変動の一例を示せば，図一3のと扤りである，図一3 から中央点の各振幅比に対応する振動数 $f$ を読み取っ た.これらを振幅比 $A$ が 0.1 以下の微小振動に達したと き $(A \approx 0)$ の振動数 $f_{1}$ で割った值から非線形自由振動 数の振幅比 $A$ と振動数比 $\bar{\omega}$ との関係が得られた.

\section{3. 結果および考察}

以上の実験法および文献 1）の解析法を用いて両端固 定はりの非線形振動挙動を検討する.

\section{(1) 振幅比 $\boldsymbol{A}$ と振動数比 $\overline{\boldsymbol{\sigma}}$ 亡の関係}

初期軸力 $P_{0}$ が作用しない場合 $\left(P_{0}=0\right)$ について, 雨端固定はりの非線形自由振動の振幅比 $A$ と振動数比 $\bar{\omega}$ との関係を示せば 表一1 のとおりである. 表において (a)，(b) 拉よび（c）欄はそれぞれ多自由度系としての 解析値 ${ }^{1}$, 偏微分方程式の差分法による digital simulation 結果 ${ }^{1}$ および実験值を示すむのである.なお, 表一1 そ抒いて, 振幅比 $A=0$ は $A \approx 0$ となる微小振動の場 合に対応するものである. 以上の (a)，(b) および (c) の結果はいずれも合致して抢り，振動数比については文 献 1)のような解析法で十分に予測可能なことが確認さ れる.はり部材に作用する初期軸力 $P_{0}$ が非線形自由振 動数に及ぼす影響を検討するために, 図一4 に振幅比 $A$ と振動数比 $\bar{\omega}$ との関係を初期軸力比 $\bar{P}_{0}$ (初期軸力 $P_{0}$ l
表-1 振幅比 $A$ と振動数比 $\overline{\boldsymbol{\sigma}}$ との関係

lution, finite-difference solution, (c)experimental result

\begin{tabular}{|l|l|l|l|l|l|l|c}
\hline & 2 & \multicolumn{1}{|c|}{3} & 4 & 5 & 6 & 7 & 5 \\
\hline 1.0222 & $1.0 \$ 54$ & 1.1824 & 1.3049 & 1.4468 & 1.6046 & 1.7771 & 1.9672 \\
\hline 1.022 & 1.085 & 1.182 & 1.305 & 1.447 & 1.559 & 1.774 & \\
\hline 1.01 & 1.08 & 1.16 & 1.27 & 1.40 & 1.59 & 1.74 & 1.95 \\
\hline
\end{tabular}

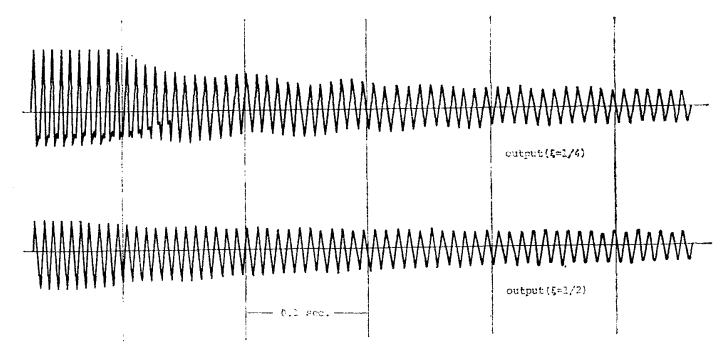

\section{図-3 非線形自由振動の時間的変動}

Euler の座屈荷重 $P_{c r}$ ) をパラメーターにプロッ トした結果を示す. $\bar{P}_{0}$ $>0$ は圧縮力の領域に, $\bar{P}_{0}<0$ は引張力にそれ ぞれ対応するものであ る. 初期軸力の影響は圧 縮力の領域でかつ振幅比 が小さい場合に顕著であ るが, 引張力の領域でか つ振幅比が大きい場合に は逆に小さくなる. 図一

4 には実験值をプロット しているが, 理論值とよ く一致している.

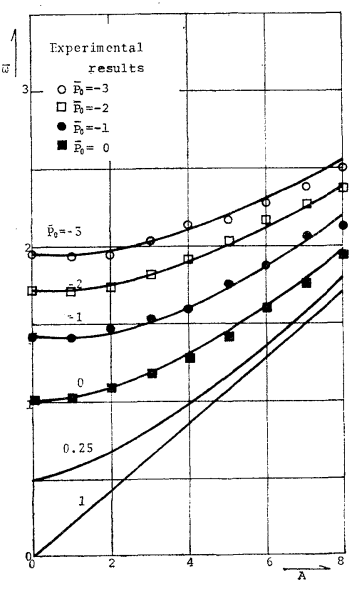

\section{図一4 非線形自由振動の振幅 比 $A$ と振動数比 $\bar{\omega}$ と の関係}

\section{（2）振幅による振動形の変動}

図一5 は初期軸力比 $\bar{P}_{0}=0$ に対するはりの 4 分の 1 点の振幅と中央点の振幅の比 $Y$ と振幅比 $A$ との関係をプ ロットしたものである. 図のように $Y$ は振幅比 $A$ ととも に増大する。拉, 図中の印印非線形自由振動実験か ら求めたものである. 振幅に伴う振動形の変化は実験值

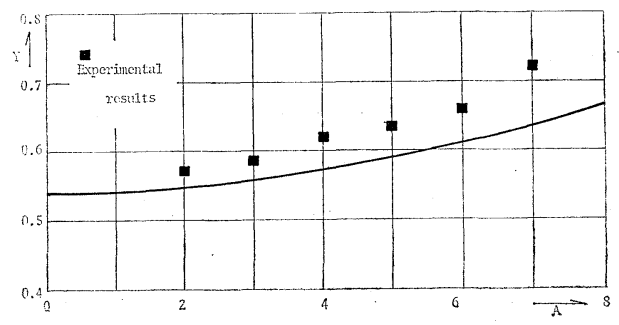

図一5 振幅に伴う振動形の変動 
とよく対応している、なお,実験值において， 振幅比 $A$ が小さい場合には読み取りが無理で あるために $A=0,1$ は省略されている．ま た，振幅比が大きい領域で実験值と解析值と の差が大きくなっている.この原因は後述の よ5に図一3に示した 4 分の 1 点の振幅が大 きい 2 次逆対称振動の 2 倍の高調波振動がこ の領域で生じているためである.

\section{（3）非線形定常強制振動}

初期軸力比 $\bar{P}_{0}=0$ に対して 周期的変動荷 重の分布強度 $\bar{p}=128$ （加振加速度 $1 \mathrm{~g}$ ）の 場合の加振振動数比 $\bar{\omega}$ (加振振動数 $/ 1$ 次対称 固有振動数）と応答振幅 $A$ （はりの中央点の 最大振幅/回転半径) の関係をプロットすれば

図一6 に示すとおりである.図中において肉太の実線は 荷重の時閒関数と同位相の非線形応答の解析值に, 点線 は逆位相の解析值にそれぞれ対応するものである。な お，本計算に用いた自由度数は 3 で， 5 倍の高調波成分 まで採用している．応答振幅に付した記号 $a_{n}{ }^{i}$ は $n$ 次振 動形の $i$ 倍の高調波応答 $(i \geq 1)$ または $i$ 倍の分数調波 応答 $(i<1)$ を意味するものである（文献 1 ) の式 $(22)$ 参照). 図中において $\bar{\omega}=1.0$ 付近に生ずる共振は加振 振動数と同じ応答振動数が卓越する 1 次対称振動の主共 振 $\left(a_{1}{ }^{1}\right)$ である. $\bar{\omega}=0.2$ および 0.33 付近で調和応答 に付随して連続的に生ずる共振は加振振動数の 5 倍およ び 3 倍の振動が卓越する 1 次振動の 5 倍 $\left(a_{1}{ }^{5}\right)$ および 3 倍の高調波共振 $\left(a_{1}{ }^{3}\right)$ である. $\bar{\omega}=1.8$ および 2.65 付 近の共振は 3 次対称振動の 3 倍 $\left(a_{3}{ }^{3}\right)$ および 5 次対称振 動の 5 倍 $\left(a_{5}{ }^{5}\right)$ の高調波共振である. また, $\bar{\omega}=1.15$ 付 近で主共振の同位相の振幅が不連続となっているが,こ れは 3 次対称振動の 5 倍の高調波成分 $\left(a_{3}{ }^{5}\right)$ と 1 次振動 の基本波の荷重と同位相成分 $\left(a_{1}{ }^{1}\right)$ が内部共振を生ずる ためである. $\bar{\omega}=3.0$ 付近に分岐的に生ずる共振は 1 次 振動の 3 分の 1 の分数調波共振 $\left(a_{1}{ }^{1 / 3}\right)$ である. なお, $\bar{\omega}=1.0$ 付近に示した細い実線と破線は対忘する線形振 動の主共振である. 線形振動の場合, 図の振動数領域で 生ずる唯一の共振である.

図中において。印は掃引振動数を増加させた場合の実 験值を, メ印は掃引振動数を減少させた場合の実験值を それぞれ示すものである.また，図中の矢印は実験で得 られた振幅のジャンプ現象の方向を示すものである.

\section{a) 主 共 振}

図一6 の振動数領域では 図一7（a）に示すような波形 をもつ 1 次振動の調和応答が生ずるが, $\bar{\omega}=1.0$ 付近の 振幅比と振動数比との関倸が非線形領域に入る主共振を はじめ広い振動数領域にわたって応答振幅の解析值は実
験值とよく一致してい る. 解析值は減衰を含ま ないために共振時の振幅 は無限大となるが，実験 では減衰を含むために振 幅の大きさは有限とな る.このために, 文献 1) の安定判別結果から予測 されるように，応答振幅 が鉛直接線をもつ位置で 過渡現象であるジャンプ 現象が生じている。

b) 高調波共振

図一6に示したように $\bar{\omega}<1.0$ の領域で, 1次 振動の振動形をもつ高調 波共振が生ずる.すなお ち, $n$ 倍の高調波共振は $\bar{\omega} \doteqdot 1 / n$ 付近で生ずる. 実験で得られた高調波共 振の一覧表を示せば 表 一2のとおりである.ま た，波形の一例が 図一7 (b) に示されている.こ れらの高調波共振のう ち, 3 倍の高調波共振が 卓越している. 解析值は 理想的な直線はりに対す る結果であるために， 3

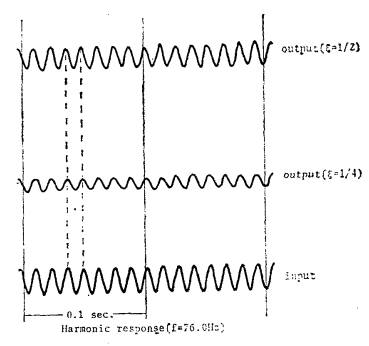

(a)

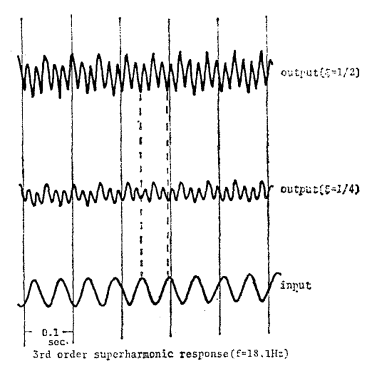

(b)

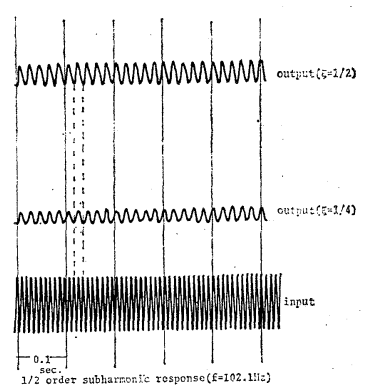

(c)

\section{図一7 非線形振動の各種の} 共振波形
倍および 5 倍の奇数次の高調波共振のみが求められてい るが，実験では $6 ， 4 ， 2$ 倍の偶数次および $3 / 2$ 倍の非整 数次の高調波共振が含まれている，直線はりの非線形振 


\section{表一2 高調波・分数調波共振の一覧表}

\begin{tabular}{c|c|c|c|c|c|c|c}
\hline order & 6 & 5 & 4 & 3 & 2 & $3 / 2$ & $1 / 2$ \\
\hline up & & & 0.22 & 0.38 & 0.40 & & 2.17 \\
\hline down & 0.15 & 0.23 & 0.25 & 0.35 & 0.51 & 0.71 & 2.02 \\
\hline
\end{tabular}

\section{表-32 次逆対称振動の不安定領域の一覧表}

\begin{tabular}{c|l|c|c|c}
\hline \multirow{2}{*}{ up } & calc. & 1st. & 2nd & 3rd \\
\hline \multirow{2}{*}{ down } & exp. & $2.26-2.33$ & $1.71-1.94$ & 0.974 \\
& calc. & 2.757 & $1.39-1.78$ & $0.94-1.04$ \\
\hline & exp. & $2.35-2.23$ & $1.24-1.22$ & 0.974 \\
\hline
\end{tabular}

動問題では復元力に 3 次の非線形項が含まれるために 3,5 倍などの奇数次の項のみが生ずるはずである.こ の矛盾ははりにわずかに存在する初期たわみによる 2 次 の非線形項に起因するものと考えられる.

3 次対称振動の高調波共振が 1 次固有振動数の領域で 生ずる. 本シリーズの実験では掃引振動数上昇時に $\bar{\omega}=$ 1.05 および 1.3 付近で 3 次振動の 5 倍および 4 倍の高 調波共振が現われた。

c) 分数調波共振

本例の実験では 図-7 (c) に示すような 1 次振動の 2 分の 1 の分数調波共振が現われ，かなり大きな振幅に成 長している. 解析では $\bar{\omega}=3.0$ 付近から 1 次振動の 3 分 の 1 の分数調波共振が現われる. この分数調波共振は高 調波共振の場合とは異なって分岐型の応答1) であるため に常に現われるとは限らない応答である.このために， 本例では 3 分の 1 の分数調波共振は生じていない.

d) 2 次逆対称振動

本例の実験模型の構造および荷重ははりの中央に対し て対称であるから，はりの動的応答も通常対称であるは ずである、しかし，図一3 の波形にみられるように主共 振の振幅比が大きい領域で 4 分の 1 点の変位が卓越する 2 次逆対称振動が生ずる.この自由度の振動形は直接加 振されないが，非線形連成項を介して対称振動によって 係数励振不安定振動が生ずるものである.

Hill の方程式で表わされる運動方程式を解いて，2次 逆対称振動が生ずる振動数領域を求めれば 表一3に示す とおりである. 第 1,2 および 3 の不安定領域は 2 次固 有振動数 $\bar{\omega}=2.757$ の $1,1 / 2$ 扝よび $1 / 3$ 付近で生じて いる. 現象的には 2 次振動の主, 2 および 3 倍の高調波 共振と同じものである.これらの不安定振動のらち, の $=1.71 \sim 1.94$ で生ずる第 2 不安定領城は広く, 定常的
に生ずるものである. 4 分の 1 点の応答をバンドバスフ ィルターにかけて 2 次振動成分のみを取り出して得られ た不安定領域の実験值が 表一3に併記されている. 実験 に颃いても解析值と同じ第 1,2 および 3 不安定領域が 得られている. 解析值と実験值と比較すると実験値の方 が不安定領域の幅が広い。

\section{4. 結語}

本研究ははりの非線形振動の実験值と解析值と比較 したものである・得られた結果を要約すると，

（1）非線形自由振動については解析值, digital simulation 結果および実験值の三者が一致する.

(2) はりの振動形は振幅によって生ずる軸力のため に振幅とともに変動して弦の振動形に近づく.この振動 形の変動は実験からも確認された.

（3）定常強制振動の解析によって主共振, 奇数次の 高調波共振および分数調波共振が得られた. 応答振幅と 加振振動数との関係は解析值と実験值とがよく一致す る. 理論では奇数次の高調波拉よび分数調波共振のみが 得られたが, 実験ではこのほかにはりの初期たわみによ ると考えられる偶数次の高調波および分数調波共振が得 られた。また実験では振幅がジャンプする過渡現象が生 ずるが，その位置は解析の応答振幅が鉛直接線をもつ位 置と合致する.

（4）実験によって特定の振動数領域で直接加振され ない 2 次逆対称振動の不安定振動が得られた. 多自由度 系の振動系特有の Hill の方程式で表わされる係数励振 不安定振動であるとみなした解析值と同じ不安定振動が 実験によって得られた。

最後に本研究の一部は昭和 53,54 年度の文部省科研 費によったことを記して謝意を表するものである．本研 究の数值計算には九州大学大型計算機センターのM-190 を使用したことを付記する。

\section{参 考 文献}

1）高橋・河原・山辺：はりおよび 薄板の非線形振動心：Galerkin 法による解析の収束性および安定性について，上 木学会論文報告集, 第 293 号, pp. 9 22, 昭和 55 年. 1 月.

(1980.6.11. 受付) 